\title{
Front Matter: Volume 9986
}

, "Front Matter: Volume 9986," Proc. SPIE 9986, Unmanned/Unattended Sensors and Sensor Networks XII, 998601 (30 November 2016); doi: $10.1117 / 12.2264041$

SPIE. Event: SPIE Security + Defence, 2016, Edinburgh, United Kingdom 


\title{
PROCEEDINGS OF SPIE
}

\section{Unmanned/Unattended Sensors and Sensor Networks XII}

\author{
Edward M. Carapezza \\ Panos G. Datskos \\ Christos Tsamis \\ Editors
}

27 September 2016

Edinburgh, United Kingdom

Sponsored by

SPIE

Cooperating Organisations

Innovation Centre for Sensor and Imaging Systems (United Kingdom)

ADS Scotland (United Kingdom)

The Knowledge Transfer Network (United Kingdom)

Visit Scotland (United Kingdom)

European Regional Development Fund (Belgium)

Technology Scotland (United Kingdom)

Published by

SPIE 
The papers in this volume were part of the technical conference cited on the cover and title page. Papers were selected and subject to review by the editors and conference program committee. Some conference presentations may not be available for publication. Additional papers and presentation recordings may be available online in the SPIE Digital Library at SPIEDigitallibrary.org.

The papers reflect the work and thoughts of the authors and are published herein as submitted. The publisher is not responsible for the validity of the information or for any outcomes resulting from reliance thereon.

Please use the following format to cite material from these proceedings:

Author(s), "Title of Paper," in Unmanned/Unattended Sensors and Sensor Networks XII, edited by Edward M. Carapezza, Panos G. Datskos, Christos Tsamis, Proceedings of SPIE Vol. 9986 (SPIE, Bellingham, WA, 2016) six-digit Article CID Number.

ISSN: 0277-786X

ISSN:1996-756X (electronic)

ISBN: 9781510603769

ISBN: 9781510603776 (electronics)

Published by

SPIE

P.O. Box 10, Bellingham, Washington 98227-0010 USA

Telephone +1 3606763290 (Pacific Time) · Fax +1 3606471445

SPIE.org

Copyright (C) 2016, Society of Photo-Optical Instrumentation Engineers.

Copying of material in this book for internal or personal use, or for the internal or personal use of specific clients, beyond the fair use provisions granted by the U.S. Copyright Law is authorized by SPIE subject to payment of copying fees. The Transactional Reporting Service base fee for this volume is $\$ 18.00$ per article (or portion thereof), which should be paid directly to the Copyright Clearance Center (CCC), 222 Rosewood Drive, Danvers, MA 01923. Payment may also be made electronically through CCC Online at copyright.com. Other copying for republication, resale, advertising or promotion, or any form of systematic or multiple reproduction of any material in this book is prohibited except with permission in writing from the publisher. The CCC fee code is 0277-786X/16/\$18.00.

Printed in the United States of America.

Publication of record for individual papers is online in the SPIE Digital Library.

\section{SPIE. DIGITAL \\ SPIEDigitallibrary.org}

Paper Numbering: Proceedings of SPIE follow an e-First publication model. A unique citation identifier (CID) number is assigned to each article at the time of publication. Utilization of CIDs allows articles to be fully citable as soon as they are published online, and connects the same identifier to all online and print versions of the publication. SPIE uses a six-digit CID article numbering system structured as follows:

- $\quad$ The first four digits correspond to the SPIE volume number.

- The last two digits indicate publication order within the volume using a Base 36 numbering system employing both numerals and letters. These two-number sets start with $00,01,02,03,04,05,06,07,08,09,0 A, 0 B \ldots$ OZ, followed by 10-1Z, 20-2Z, etc. The CID Number appears on each page of the manuscript. 


\title{
Contents
}

\author{
$\checkmark$ Authors \\ vii Conference Committee
}

\section{KEYNOTE SESSION I}

998602 Perception and estimation challenges for humanoid robotics: DARPA Robotics Challenge and NASA Valkyrie (Invited Paper) [9986-1]

UNMANNED/UNATTENDED AIR SENSORS AND SYSTEMS

998604 Multibeam monopulse radar for airborne sense and avoid system [9986-3]

998605 Using crowd sourcing to combat potentially illegal or dangerous UAV operations [9986-4]

998606 Optical flow and inertial navigation system fusion in the UAV navigation [9986-5]

\section{KEYNOTE SESSION II}

9986 OA Power for sensors; sensors for power (Invited Paper) [9986-9]

9986 OB Collaborative autonomous sensing with Bayesians in the loop (Invited Paper) [9986-10]

\section{UNMANNED/UNATTENDED GROUND SENSORS AND SYSTEMS}

9986 OC Tunable mechanical monolithic sensors for large band low frequency monitoring and characterization of sites and structures [9986-11]

9986 OD Data fusion for target tracking and classification with wireless sensor network [9986-13] UNMANNED/UNATTENDED SENSORS AND TECHNOLOGIES

9986 OG Laser ablation method for production of surface acoustic wave sensors [9986-16] 


\title{
Authors
}

Numbers in the index correspond to the last two digits of the six-digit citation identifier (CID) article numbering system used in Proceedings of SPIE. The first four digits reflect the volume number. Base 36 numbering is employed for the last two digits and indicates the order of articles within the volume. Numbers start with 00, 01, 02, 03, 04, 05, 06, 07, 08, 09, 0A, 0B...0Z, followed by 10-1Z, 20-2Z, etc.

\author{
Acernese, F., OC \\ Ahmed, Nisar, $O B$ \\ Barone, F., OC \\ Canevet, Loic, OD \\ Dezert, Jean, OD \\ Doumerc, Robin, OD \\ Fallon, Maurice, 02 \\ Giordano, G., OC \\ Gorwara, Ashok, 04 \\ Kukaev, Alexander, OG \\ Lukyanov, Dmitry, OG \\ Miller, A., 06 \\ Miller, B., 06 \\ Molchanov, Pavlo, 04 \\ Moras, Julien, OD \\ Pannetier, Benjamin, OD \\ Popov, A., 06 \\ Romano, R., OC \\ Safronov, Daniil, OG \\ Shevchenko, Sergey, OG \\ Siegel, Mel, OA \\ Stepanyan, K., 06 \\ Tapsall, Brooke T., 05
}




\section{Conference Committee}

Symposium Chair

David H. Titterton, United Kingdom Defense Academy

(United Kingdom)

Symposium Co-chairs

Ric Schleijpen, TNO Defence, Security and Safety (Netherlands)

Karin Stein, Fraunhofer-Institut für Optronik, Systemtechnik und

Bildauswertung (Germany)

Stuart S. Duncan, Leonardo-Finmeccanica (United Kingdom)

Conference Chairs

Edward M. Carapezza, EMC Consulting LLC (United States)

Panos G. Datskos, Oak Ridge National Laboratory (United States)

Christos Tsamis, National Center for Scientific Research Demokritos

(Greece)

Conference Programme Committee

Mehdi F. Anwar, University of Connecticut (United States)

Mark E. Campbell, Cornell University (United States)

John M. Dolan, Carnegie Mellon University (United States)

Grant R. Gerhart, Consultant (United States)

Todd M. Hintz, Space and Naval Warfare Systems Command (United States)

Myron E. Hohil, U.S. Army Armament Research, Development and Engineering Center (United States)

Ivan Kadar, Interlink Systems Sciences, Inc. (United States)

Tariq Manzur, Naval Undersea Warfare Center (United States)

George C. McNamara, Naval Undersea Warfare Center (United States)

Andre Samberg, Sec-Control Innovation (Finland)

Huub A.J.M. van Hoof, TNO Defence, Security and Safety

(Netherlands)

Session Chairs

1 Keynote Session I

Edward M. Carapezza, EMC Consulting LLC (United States)

Panos G. Datskos, Oak Ridge National Laboratory (United States) 
2 Unmanned/Unattended Air Sensors and Systems

Edward M. Carapezza, EMC Consulting LLC (United States)

Panos G. Datskos, Oak Ridge National Laboratory (United States)

3 Unmanned/Unattended Maritime Sensors and Systems

Edward M. Carapezza, EMC Consulting LLC (United States)

Panos G. Datskos, Oak Ridge National Laboratory (United States)

4 Keynote Session II

Edward M. Carapezza, EMC Consulting LLC (United States)

Panos G. Datskos, Oak Ridge National Laboratory (United States)

5 Unmanned/Unattended Ground Sensors and Systems

Edward M. Carapezza, EMC Consulting LLC (United States)

Panos G. Datskos, Oak Ridge National Laboratory (United States)

6 Unmanned/Unattended Sensors and Technologies

Edward M. Carapezza, EMC Consulting LLC (United States)

Panos G. Datskos, Oak Ridge National Laboratory (United States) 